\title{
MONITORING OF RHAGOLETIS CERASI L. THROUGH THE DECIS TRAP AT IAȘI-ROMANIA
}

\author{
Simona-Mihaela Chelaru ${ }^{1}$, Cristina-Ionela Turcu ${ }^{{ }^{*}}$, Margareta Corneanu ${ }^{1}$, Ionel Perju ${ }^{1}$ \\ ${ }^{1}$ Research Station for Fruit Growing Iaşi, România
}

\begin{abstract}
Rhagoletis cerasi (L.) is the main agent of damage to sweet cherry plantations. Found in all sweet cherry plantations, it is important for an integrated phytosanitary protection of the crop. The population dynamics in the Iasi area was monitored at different time intervals. The climatic conditions of the year and the biological reserve favored the appearance and development of the pest studied. The first catches were recorded on 12 May and the highest number of catches was recorded on 17 June 2020. Adult monitoring Rhagoletis cerasi (L.) was performed using "Decis Trap", an attractive trap containing ammonium carbonate, which attracts by its orange color and fights with the active substance deltamethrin providing a duration of protection of 5 months. The appearance and dynamics of pests have directly influenced the phytosanitary protection program. The observations were made during the vegetation period of the cherry plantation within the Research and Development Station for fruit growing in Iași in 2020.
\end{abstract}

Keywords: biological control, fruit, protection, sweet cherries, traps.

\section{INTRODUCTION}

Cherry fly, the main pest of cherry plantations is reported in Asia (8 countries), Europe (34 countries) and North America (CABI, 2021).

The attack of the pest Rhagoletis cerasi L. in cherry plantations determines the application of control measures to obtain a qualitative and quantitative harvest (S. Stamenkovic et al., 1996).

Rhagoletis cerasi L. is considered a pest that causes damage to fruit by depreciating it, becoming non-commercial given that the attack occurs when the fruit ripens.

With the help of the new Decis trap traps considered biological we can fight but also monitor the pest, representing the future in the fight against the pest. Biological control of pests is an important measure of integrated pest management.

\section{MATERIALS AND METHODS}

The research was carried out in 2020 in an experimental cherry plantation on the varieties Maria, Bucium, Tereza, aimed at the emergence of the pest Rhagoletis cerasi L. and its control with the help of new traps based on deltamethrin - decided trap.

In May, when the cherry was in the fruit-binding phenophase, a number of 5 traps were placed. Decis trap containing the active substance deltamethrin belongs to the chemical group of synthetic pyrethroids and acts by contact and ingestion on harmful insects both in the larval stage, as well as 
in the adult one. The product has a shock effect and a variable duration of activity depending on local conditions. The principle behind which decidedly trap works is to attract and combat as many adult flies (females and males) in order to reduce the number of larvae below the economic threshold of damage during the period when the crop is highly susceptible. the trap contains an amount of $0.015 \mathrm{~g} /$ trap active substance.

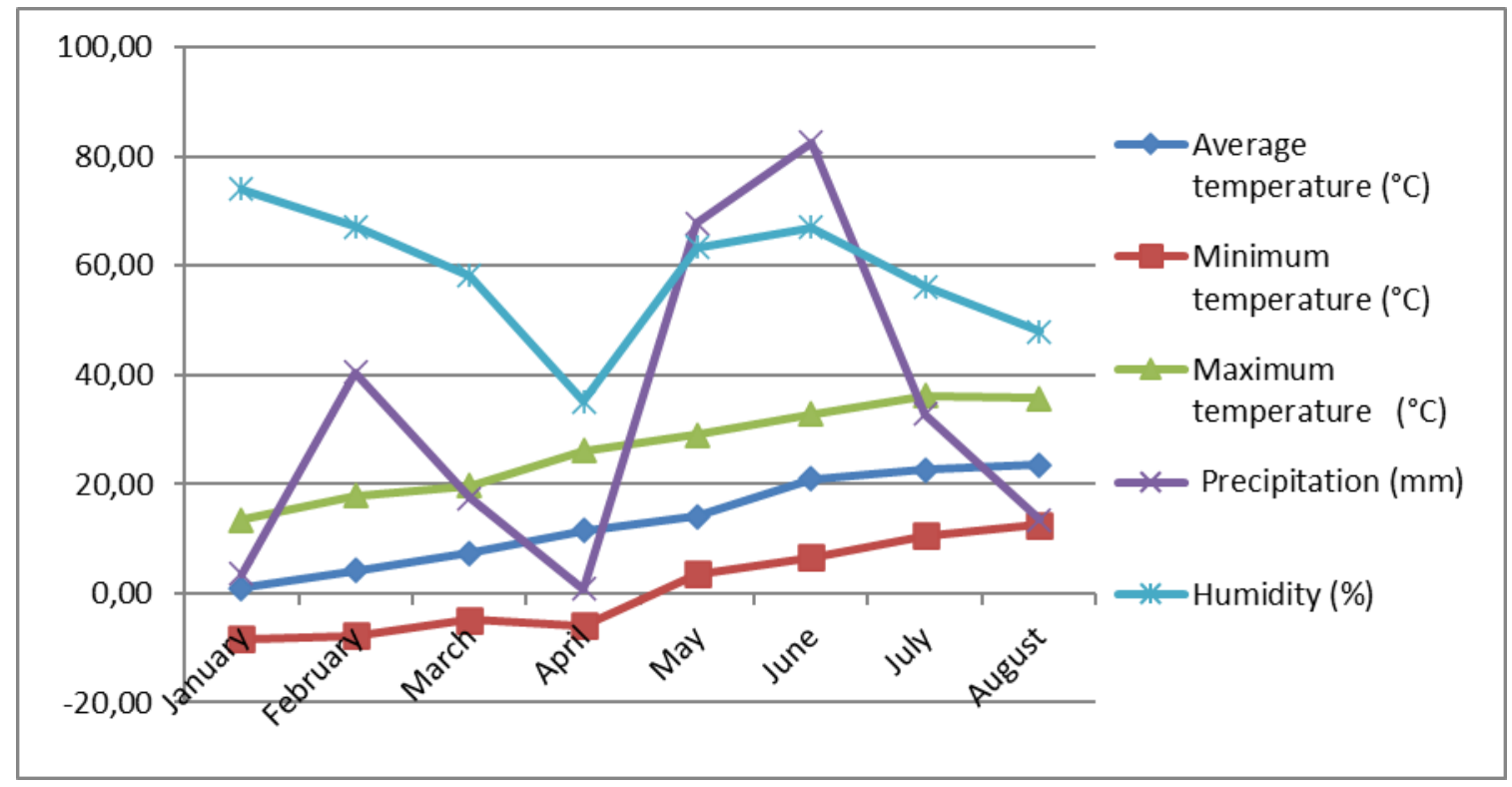

Figure 1. Climatic situation during the studied period

The climatological situation of the study period (fig. 1) is favorable for the growth and development of cherry plantations. The average temperature of the vegetation period was between $0.93{ }^{\circ} \mathrm{C}$ and $23.57^{\circ} \mathrm{C}$.

The temperature ranged from a low of $-8.4^{\circ} \mathrm{C}$ to a high of $12.6^{\circ} \mathrm{C}$. The summary of precipitation in the first half of the year is $258.8 \mathrm{~mm}$, being below the average annual rainfall threshold of 700 $\mathrm{mm}$. The humidity varied between the minimum of $35.07 \%$ in April and the maximum of $73.97 \%$ in January.

\section{RESULTS AND DISCUSSIONS}

Examining figure 3 in which we find the catches recorded in the analyzed period, the environmental conditions were favorable for the attack, characteristic of the warm spring contributing to the appearance in the first decade of May.

The first occurrence of the pest was recorded on May 12, and the highest number of catches was recorded on July 10 with a number of 24 insects. The number of catches was higher between June 9 and July 10 when the cherries were being harvested or even harvested. The number of catches was also influenced by the fact that no phytosanitary treatments were applied. 


\section{Current Trends in Natural Sciences}

Vol. 10, Issue 19, pp. 36-39, 2021

https://doi.org/10.47068/ctns.2021.v10i19.004

Current Trends in Natural Sciences (on-line)
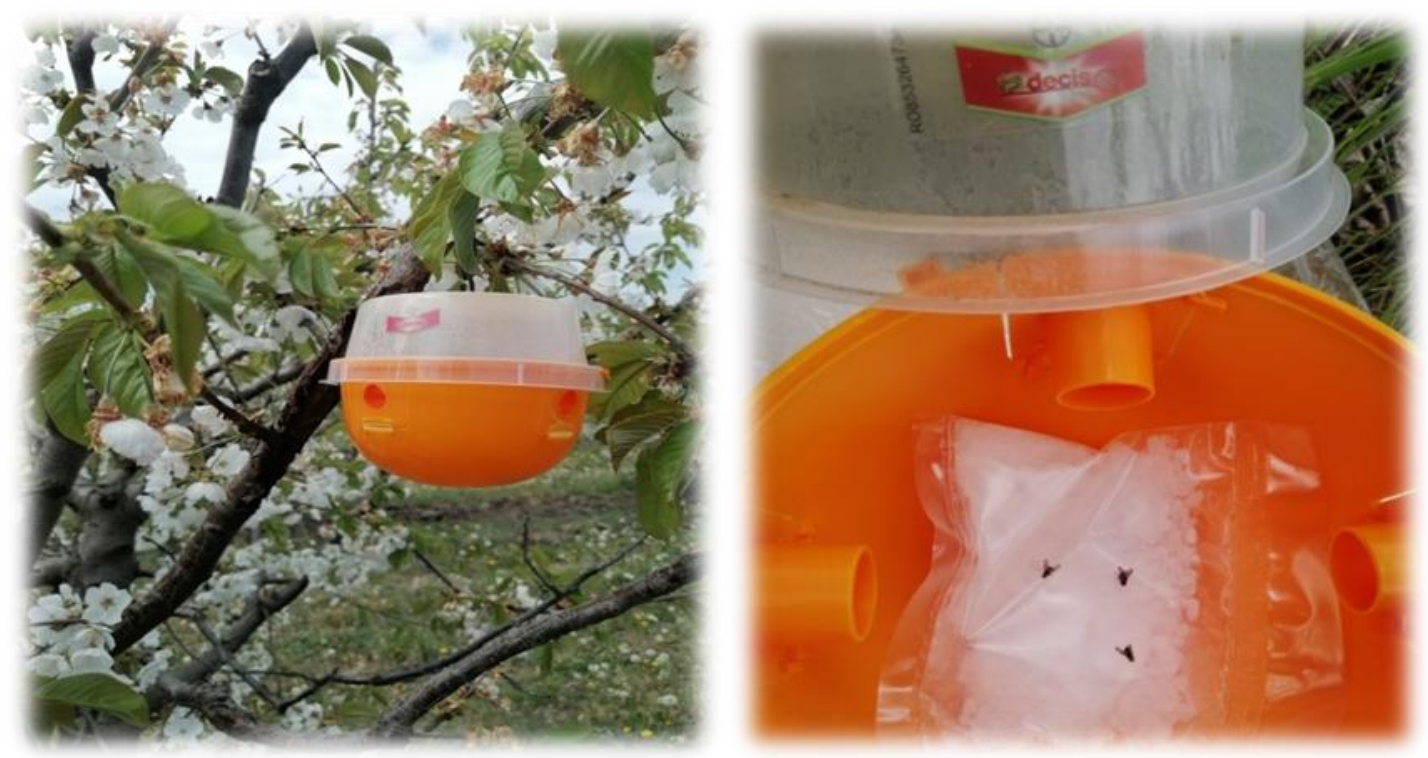

Figure 2. Rhagoletis cerasi L. captured with Decis trap et the flight start and maximum flight curve

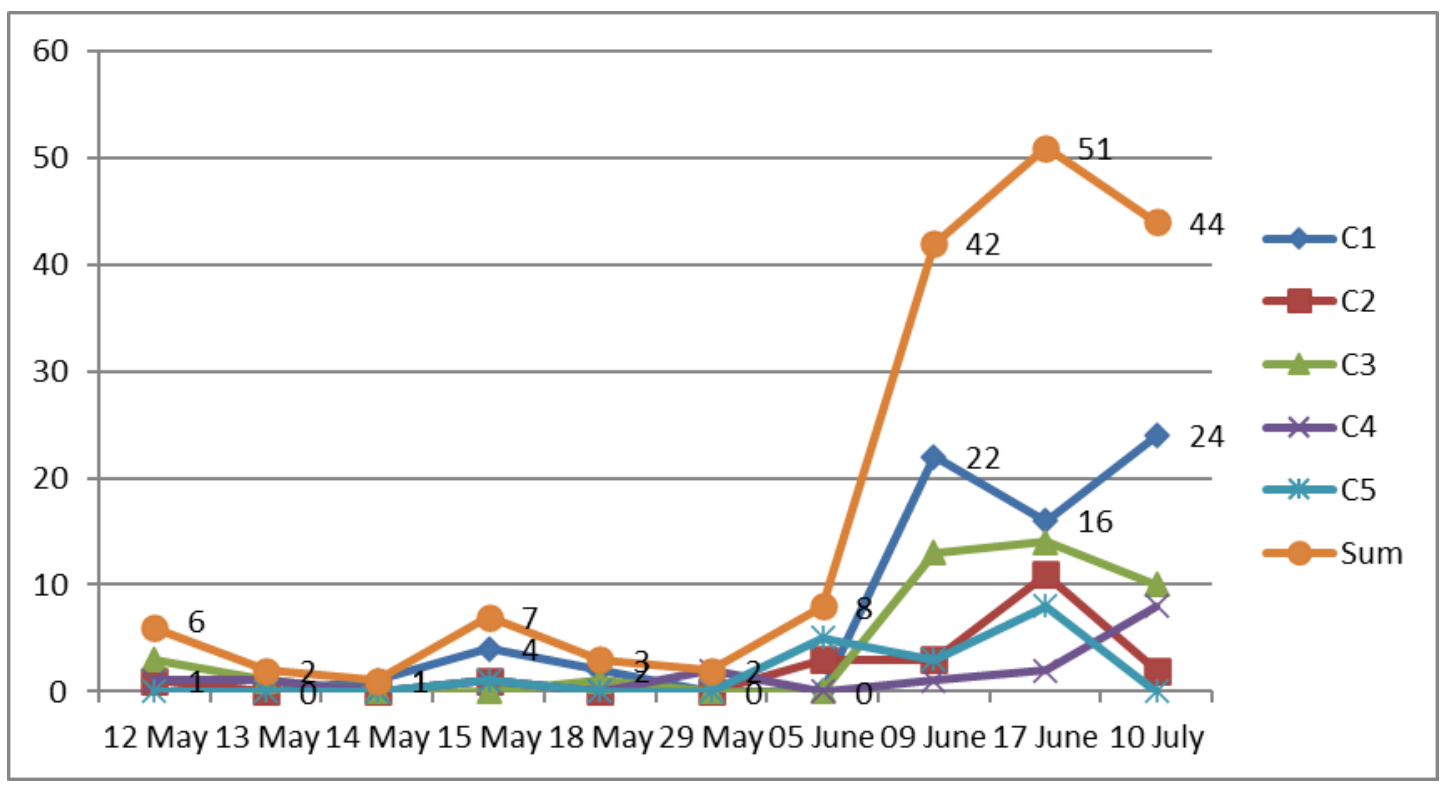

Figure 3. Monitoring the flight of the Rhagoletis cerasi L. cherry pest through DECIS Trap, SCDP IASI 


\section{Current Trends in Natural Sciences}

Vol. 10, Issue 19, pp. 36-39, 2021

https://doi.org/10.47068/ctns.2021.v10i19.004

Current Trends in Natural Sciences (on-line)

Table 1. Treatment programme, 2020 at SCDP IASI

\begin{tabular}{|c|c|c|c|}
\hline $\begin{array}{c}\text { NO. } \\
\text { TREATMENT } \\
\text { PHENOPHASE }\end{array}$ & $\begin{array}{l}\text { SPECTRUM OF } \\
\text { COMBAT }\end{array}$ & PRODUCTS & CONCENTRATION \% \\
\hline \multirow[b]{3}{*}{$\begin{array}{c}\text { Treatment } 1 \\
\text { BBCH } 53\end{array}$} & \multirow{3}{*}{$\begin{array}{c}\text { Quadraspidiotus } \\
\text { perniciosus, Myzus } \\
\text { cerasi,Panonychus ulmi, } \\
\text { Monilinia sp., Stigmina } \\
\text { carpophylla,Coccomyces } \\
\text { heimalis. } \\
\end{array}$} & B. Bordelaise & $0.5 \%$ \\
\hline & & Mospilan 20 SG & $0.03 \%$ \\
\hline & & Polyactiv B & $0.1 \%$ \\
\hline \multirow[b]{3}{*}{$\begin{array}{c}\text { Treatment } 2 \\
\text { BBCH } 71\end{array}$} & \multirow{3}{*}{$\begin{array}{c}\text { Quadraspidiotus } \\
\text { perniciosus, Myzus } \\
\text { cerasi,Panonychus ulmi, } \\
\text { Monilinia sp., Stigmina } \\
\text { carpophylla,Coccomyces } \\
\text { heimalis. } \\
\end{array}$} & $\begin{array}{l}\text { Signum } \\
\end{array}$ & $0.05 \%$ \\
\hline & & Calypso 480 sc & $0.02 \%$ \\
\hline & & Polyactiv B & $0.1 \%$ \\
\hline \multirow{3}{*}{$\begin{array}{l}\text { Treatment } 3 \\
\text { BBCH } 81\end{array}$} & \multirow{3}{*}{$\begin{array}{c}\text { RHAGOLETIS T1- Myzus } \\
\text { cerasi,Panonychus ulmi, } \\
\text { Monilinia sp., Stigmina } \\
\text { carpophylla,Coccomyces } \\
\text { heimalis. }\end{array}$} & Folicur solo & $0.075 \%$ \\
\hline & & Rezistevo & $0.4 \%$ \\
\hline & & Decis 25 wg & $0.004 \%$ \\
\hline \multirow{3}{*}{$\begin{array}{c}\text { Treatment } 4 \\
\text { BBCH } 85\end{array}$} & \multirow{3}{*}{$\begin{array}{l}\text { RHAGOLETIS T2- Myzus } \\
\text { cerasi,Panonychus ulmi, } \\
\text { Monilinia sp., Stigmina } \\
\text { carpophylla,Coccomyces } \\
\text { heimalis. } \\
\end{array}$} & Topsin 70 wdg & $0.07 \%$ \\
\hline & & Calypso $480 \mathrm{sc}$ & $0.02 \%$ \\
\hline & & Rezistevo & $0.3 \%$ \\
\hline
\end{tabular}

\section{CONCLUSIONS}

The climatic conditions of the year favored the appearance of pests in the cherry plantations of the studied area. Prevention and control methods have helped to limit the pest threshold. The application of phytosanitary treatments had a very important role in the number of catches recorded so that towards the end of the insecticide coverage period the flight curve intensified, registering a maximum number of 24 catches per trap.

\section{REFERENCES}

Beratlief, C., Ionescu, C., Mustatea, D. (1981), Observations on the effectiveness of the visual traps in the monitoring of treatments against the cherry fly (Rhagoletis cerasi L.). Bulletin de l'Academie des Sciences Agricoles et Forestieres, 93-102.

CABI (2021). Crop Protection Compendium. (CABI). (Last accessed January 2021.)

Macaveli, L., Oltean, I., Florian, T., Varga, M., Mitre, V., Soporan, C., (2013). Monitoring European Cherry Fruit Fly (Rhagoletis Cerasi L.) Through Vizual Traps. Bulletin of University of Agricultural Sciences and Veterinary Medicine. 70 (2), 443-444.

Stamenković, S., Milenković, S., Stamenković, T. (1996). Population dynamics of Rhagoletis cerasi L. (Diptera, Tephritidae) in western Serbia. Acta Horticulturae. 561-565.

www.naturevo.ro. 